\title{
Effect of Different Organic Sources on Fenugreek (Trigonella foenum-graecum L.) under Organic Farming Module
}

\author{
J.K. Malav*, J.K. Patel, R.P. Pavaya, B.B. Patel and V.R. Patel \\ Department of Agricultural Chemistry and Soil Science, C.P. College of Agriculture, S.D. \\ Agricultural University, Sardarkrushinagar-385 506, Gujarat, India \\ *Corresponding author
}

\begin{tabular}{l}
\hline Ke y w or d s \\
$\begin{array}{l}\text { Fenugreek, Organic } \\
\text { farming, Yield, } \\
\text { Nutrients }\end{array}$ \\
\hline Article Info \\
$\begin{array}{l}\text { Accepted: } \\
\text { 04 January } 2018 \\
\text { Available Online: } \\
\text { 10 February } 2018\end{array}$ \\
\hline
\end{tabular}

\section{Introduction}

Fenugreek is an important versatile rabi season seed spice crop mainly grown in Rajasthan, Gujarat, Madhya Pradesh Maharashtra and Haryana. The seeds of

\section{A B S T R A C T}

A field experiment on the standardization of organic module for production of fenugreek (Trigonella foenum graecum L.) was conducted during rabi season of 2007-08 and 200809 (two years). The experiment comprising of absolute control and varying proportion of organic and inorganic sources viz., $100 \%$ Recommended Dose of N through FYM, $100 \%$ RDN through castor cake, Rhizobium treatment, PSB treatment, Rhizobium + PSB treatment, $50 \%$ Recommended Dose of $\mathrm{N}$ through FYM + Rhizobium, $50 \%$ Recommended Dose of $\mathrm{N}$ through $\mathrm{CC}+$ Rhizobium, $50 \%$ RDN through FYM + Rhizobium + PSB, $50 \%$ Recommended Dose of N through CC + Rhizobium + PSB) and Recommended dose of fertilizer was laid out in randomized block design with four replications. It was found that RDF and varying combinations of organic sources produced significantly higher grain yield over absolute control. The seed and straw yield of fenugreek was found significant due to different treatments, wherein integrated use of organic sources of nitrogen (50\% RDN through castor cake + Rhizobium + PSB) recorded significantly higher seed and straw yield of fenugreek as compared to their individual use. Different treatments were failed to produce significant effect on nutrient content in seed and straw of fenugreek, but it was found significant with respect to nutrients uptake, wherein higher removal of nutrients by seed and straw were noticed under integrated use of organic sources of nitrogen as well as chemical fertilizer. The organic carbon and available phosphorus were also found significant due to different treatments, whereas the maximum amount of organic carbon was registered under $100 \%$ RDN through FYM/castor cake. The maximum available phosphorus was recorded with the use of PSB and available potassium was found non-significant due to different treatments. Thus, it can be inferred that application of $50 \%$ RDN through CC + Rhizobium + PSB is better for realizing good soil health and sustainable higher yield levels. 
resulted in heavy removal of nutrients from the soil. Thus, there is a wide gap between the nutrients removed from the soil and the nutrient supplied. This gap can be bridged with the use of chemical fertilizers along with organic sources. Exclusive application of inorganic fertilizers leads to deterioration in soil health and soil structure. Conjunctive use of inorganic and organic sources of nutrients not only supplies nearly all nutrients throughout the growing period of crop but also sustain soil health. Combined use of inorganic fertilizers with organic manures in general enhances microbial activity of soil and biological nitrogen fixation in particularly. Integrated use of chemical fertilizers as well as organic manures in fenugreek can be a more efficient, economical and judicious approach than chemical fertilizers alone. Therefore, the study was undertaken to evaluate the effect of different combinations of organic and inorganic nutrient sources on productivity of fenugreek.

Recent trends in agriculture are centred on reducing the use of inorganic fertilizers by organic manures and biofertilizers (Gyaneshwar et al., 2002 and Darzi et al., 2011). Besides improving soil health, organic manures supply the major nutrients and micronutrients (Palaniappan and Annadurai, 1999). Many studies showed that organic nutrients could enhance the vegetative growth and yield of seed spices like fennel (Darzi et al., 2008) and coriander (Lal and Singh, 2016). The cultivation of seed spices including fenugreek is predominant in the Arid and semi-arid regions of Rajasthan and Gujarat. Seed spices are well adapted to poor resource conditions like water and nutrients since these crops are low input requiring crops. Fenugreek (Trigonella foenum graecum L.) is one of the major seed spice crops grown throughout the country. India produces 113000 tonnes of fenugreek annually from 93000 ha area (Tiwari et al., 2013).
Gujarat is the leading state in fenugreek production and it grows mainly in Mehsana, Patan, Sabarkantha, Banaskantha and Kheda districts. The average productivity of fenugreek in the country seems to be very low $(1215 \mathrm{~kg} / \mathrm{ha})$ which required to be increased (Lal et al., 2015). The main factors responsible for low productivity are poor soil fertility, non-availability of high yielding varieties under organic system and persistence of several biotic and a-biotic factors. Development of location and crop specific organic modules containing required quantity of nutrients, plant protection means for fenugreek cultivation is also necessary. Since, fenugreek is affected by several diseases like root rot, wilt, powdery mildew and insect pests like aphids, thrips, jassids during the cropping season, which are to be managed effectively through organic/ biological means.

Organic products are highly remunerative due to higher demand in domestic market in metro cities and for export earnings. Organic cultivation not only helps in enhancing availability of nutrients to plant, but also reduces dependency upon external inputs as it is near to nature (Lampkin, 1999). Fenugreek crop responds well to the application of both organic manures and inorganic fertilizers. Looking to its medicinal properties, there is great demand for organically produced fenugreek in the domestic and international market. Application of right and appropriate nutritional sources through manures and bio fertilizers and management of diseases and pest by organic sources improve the quality of produce with higher yield without any residual toxicity of pesticides. However, information on this aspect for fenugreek crop is very meagre. Keeping in view the above facts, besides the nutritional strength, medicinal properties and common use of fenugreek, the present study was carried out to standardize organic module for sustainable fenugreek production. 


\section{Materials and Methods}

A field experiment on "Effect of different organic sources on fenugreek (Trigonella foenum-graecum L.) under organic farming" was carried out at Agronomy Instructional Farm, S.D. Agricultural University, Sardarkrushinagar, Gujarat, during 'rabi' seasons of 2007-08 and 2008-09 (02 years). The soil had $\mathrm{pH} 7.8$ and electrical conductivity $0.23 \mathrm{dSm}^{-1}$.

The soil was low in organic carbon (0.26) and available nitrogen (142 $\left.\mathrm{kg} \mathrm{ha} \mathrm{ha}^{-1}\right)$, low in available $\mathrm{P}_{2} \mathrm{O}_{5}\left(45 \mathrm{~kg} \mathrm{ha}^{-1}\right)$ and medium in respect to available $\mathrm{K}_{2} \mathrm{O}\left(178 \mathrm{~kg} \mathrm{ha}^{-1}\right)$.

Ten treatments $\left(\mathrm{T}_{1}: 100 \%\right.$ Recommended Dose of $\mathrm{N}$ through FYM, $\mathrm{T}_{2}: 100 \%$ RDN through castor cake, $\mathrm{T}_{3}$ : Rhizobium treatment, $\mathrm{T}_{4}$ : PSB treatment, $\mathrm{T}_{5}$ : Rhizobium + PSB treatment, $\mathrm{T}_{6}: 50 \%$ Recommended Dose of $\mathrm{N}$ through FYM + Rhizobium, $\mathrm{T}_{7}: 50 \%$ Recommended Dose of $\mathrm{N}$ through $\mathrm{CC}+$ Rhizobium, $\mathrm{T}_{8}$ : $50 \%$ RDN through FYM + Rhizobium + PSB, $\mathrm{T}_{9}: 50 \%$ Recommended Dose of $\mathrm{N}$ through CC + Rhizobium + PSB and $\mathrm{T}_{10}$ : Recommended dose of fertilizer) were laid in randomized block design with three replications.

Full dose of nitrogen and phosphorus and organic manures as per treatment was applied manually through DAP, urea, poultry manure and vermicompost at the time of sowing. It was sown manually at $30 \mathrm{~cm}$ row to row spacing keeping seed rate of $20 \mathrm{~kg}$ per ha.

The fenugreek variety Gujarat Methi-2 was sown in November during 2007-08 and 200809. Standard agronomic practices were adopted for raising healthy crop.

Data of growth and yield attributes were taken from 10 tagged plants. Biological and economic yields were taken from net plot.

\section{Results and Discussion}

\section{Grain and straw yield}

Data in Table 1 illustrated that the application of different treatments of organic and inorganic fertilizers had significant effect on grain and straw yield of fenugreek during both individual years. The lowest grain (824 and $870 \mathrm{~kg} \mathrm{ha}^{-1}$ ) and straw yield (1557 and 2602 $\mathrm{kg} \mathrm{ha}^{-1}$ ) was observed with the application of PSB treatment during both the years. The maximum grain (1212 and $1106 \mathrm{~kg} \mathrm{ha}^{-1}$ ) and straw yield (2217 and $2895 \mathrm{~kg} \mathrm{ha}^{-1}$ ) was recorded due to application of $50 \% \mathrm{RDN}$ through $\mathrm{CC}+$ Rhizobium + PSB during both individual years. However, grain yield of fenugreek was at par with treatments $T_{7}, T_{8}$ and $\mathrm{T}_{10}$ during first year but, in case of second year it was at par with treatment $\mathrm{T}_{8}(50 \%$ RDN through FYM + Rhizobium + PSB). On the other hand, straw yield of fenugreek was at par with treatments $\mathrm{T}_{7}, \mathrm{~T}_{8}$ and $\mathrm{T}_{10}$ during first year, and second year it was at par with treatment $\mathrm{T}_{1}, \mathrm{~T}_{2}, \mathrm{~T}_{5}, \mathrm{~T}_{6}, \mathrm{~T}_{7}$ and $\mathrm{T}_{8}$. The application of PSB enhances root and shoot length, plant biomass and vigour, all leading to a better growth of the plant due to the production of metabolites such as phytohormone and antibiotics which finally promotes the plant growth and grain yield (Balachandran and Nagarajan, 2002). The effect of seed inoculation with Rhizobium resulted in increased number of branches and plant height at different growth stages. These parameters have been reported to have significant positive correlation with the acetylene reduction and nitrogen fixation resulting in improved nitrogen nutrient of plant. On the other hand, $\mathrm{N}_{2}$ fixed by Rhizobium translocated to plant system through xylem vessels mainly in the form of asparagines and to same extent as glutamine. These are involved in the synthesis of various enzymatic processes and variety of oxidation and reduction reactions which enhanced the 
synthesis of carbohydrates and protein. This might have helped in improved growth parameters with Rhizobium inoculation. These findings are in corroboration with the results reported by Nagarajan and Balachandran (2001) and Sibbal and Khurana (2002). Mehta et al., (2010) in cumin also reported increase in plant height, leaf area index and branches per plant with seed inoculation by Rhizobium and PSB. Thus balanced nutrients under favourable environment might have helped in production of new tissues and development of new shoots in fenugreek plants, which ultimately increased the yield attributes and grain yield. Similar findings were also reported by Lal and Singh (2016) in coriander.

The increase in yield may be attributed to better utilization of organic $\mathrm{N}$, greater biological $\mathrm{N}$ fixation, higher synthesis of plant growth hormones and enhanced availability of $\mathrm{P}$ in the presence of biofertilizers. Rhizobium and PSB play an important role in the development of meristematic tissues at growing points for promoting growth and also aid in formation of seeds in plant. Increase in seed yield due to inoculation by Rhizobium and PSB has also been recorded in other crops like soybean (Saxena et al., 2001), cumin (Mehta et al., 2010) and fenugreek (Mehta $e t$ al., 2011) (Table 2).

\section{Nutrient content and uptake}

Different treatments were failed to produce significant effect on nutrient content in seed and straw of fenugreek, but it was found significant with respect to nutrients uptake, wherein higher removal of nutrients by seed and straw were noticed under integrated use of organic sources of nitrogen as well as chemical fertilizer. Significantly, maximum nitrogen uptake by grain $(24.88$ and $21.32 \mathrm{~kg}$ $\mathrm{ha}^{-1}$ ) was recorded due to application of $50 \%$ RDN through CC + Rhizobium + PSB during both individual years. Significantly, the highest phosphorus uptake by seed (5.55 and $5.16 \mathrm{~kg} \mathrm{ha}^{-1}$ ) was recorded due to application of $50 \%$ RDN through FYM + Rhizobium+ PSB as compared to other treatments during both individual years. Significantly, maximum potassium uptake by grain $\left(11.25 \mathrm{~kg} \mathrm{ha}^{-1}\right)$ was recorded due to application of recommended dose of fertilizer during first year.

Table.1 Effect of different treatments on seed and straw yield of fenugreek (02 years)

\begin{tabular}{|c|c|c|c|c|c|}
\hline \multicolumn{2}{|c|}{ Treatments } & \multicolumn{2}{|c|}{ Seed Yield $\left(\mathrm{kg} \mathrm{ha}^{-1}\right)$} & \multicolumn{2}{|c|}{ Straw Yield (kg ha $\left.{ }^{1}\right)$} \\
\hline & & 2007-08 & 2008-09 & 2007-08 & 2008-09 \\
\hline $\mathbf{T}_{1}$ & $100 \%$ RDN through FYM & 824 & 870 & 1557 & 2602 \\
\hline $\mathbf{T}_{2}$ & $100 \%$ RDN through castor cake & 917 & 859 & 1700 & 2621 \\
\hline $\mathbf{T}_{3}$ & Rhizobium treatment & 804 & 715 & 1200 & 2350 \\
\hline $\mathbf{T}_{4}$ & PSB treatment & 784 & 730 & 1383 & 2356 \\
\hline $\mathbf{T}_{5}$ & Rhizobium + PSB & 934 & 885 & 1433 & 2632 \\
\hline $\mathbf{T}_{6}$ & $50 \%$ RDN through FYM+ Rhizobium & 1019 & 893 & 1817 & 2742 \\
\hline $\mathbf{T}_{7}$ & $50 \%$ RDN through CC + Rhizobium & 1079 & 958 & 2133 & 2759 \\
\hline $\mathbf{T}_{8}$ & $50 \%$ RDN through FYM + Rhizobium+ PSB & 1119 & 1011 & 2100 & 2705 \\
\hline $\mathbf{T}_{9}$ & $50 \%$ RDN through CC + Rhizobium+ PSB & 1212 & 1106 & 2217 & 2895 \\
\hline $\mathbf{T}_{10}$ & Recommended dose of fertilizer & 1058 & 606 & 2117 & 1736 \\
\hline & $\begin{array}{c}\text { Mean } \\
\end{array}$ & 975 & 863 & 1766 & 2539 \\
\hline & S.Em \pm & 61.44 & 46.67 & 101.42 & 173.33 \\
\hline & CD $5 \%$ & 178.3 & 126.67 & 294.32 & 506.67 \\
\hline & CV \% & 12.60 & 10.16 & 11.49 & 13.77 \\
\hline
\end{tabular}


Table.2 Effect of different treatments on nutrient content in seed of fenugreek (02 years)

\begin{tabular}{|c|c|c|c|c|c|c|c|}
\hline \multirow{3}{*}{\multicolumn{2}{|c|}{ Treatments }} & \multicolumn{6}{|c|}{ Nutrient Content in Seed (\%) } \\
\hline & & \multicolumn{2}{|c|}{$\mathbf{N}$} & \multicolumn{2}{|c|}{$\mathbf{P}$} & \multicolumn{2}{|c|}{$\mathbf{K}$} \\
\hline & & 2007-08 & 2008-09 & 2007-08 & 2008-09 & 2007-08 & $2008-09$ \\
\hline$T_{1}$ & $100 \%$ RDN through FYM & 2.04 & 1.93 & 0.41 & 0.43 & 1.02 & 1.01 \\
\hline $\mathbf{T}_{2}$ & $100 \%$ RDN through castor cake & 2.04 & 1.93 & 0.41 & 0.42 & 1.03 & 1.01 \\
\hline$T_{3}$ & Rhizobium treatment & 2.05 & 1.94 & 0.42 & 0.44 & 0.99 & 0.97 \\
\hline $\mathbf{T}_{4}$ & PSB treatment & 2.05 & 1.94 & 0.46 & 0.48 & 1.01 & 1.00 \\
\hline$T_{5}$ & Rhizobium + PSB & 2.08 & 1.96 & 0.48 & 0.50 & 1.03 & 1.01 \\
\hline$T_{6}$ & $50 \%$ RDN through FYM+ Rhizobium & 2.10 & 1.96 & 0.49 & 0.51 & 1.09 & 1.07 \\
\hline $\mathbf{T}_{7}$ & $50 \%$ RDN through CC + Rhizobium & 2.09 & 1.97 & 0.49 & 0.50 & 0.97 & 0.95 \\
\hline $\mathbf{T}_{8}$ & $50 \%$ RDN through FYM + Rhizobium+ PSB & 2.07 & 1.96 & 0.50 & 0.51 & 0.92 & 0.91 \\
\hline $\mathrm{T}_{9}$ & $50 \%$ RDN through CC + Rhizobium+ PSB & 2.05 & 1.93 & 0.44 & 0.45 & 0.90 & 0.89 \\
\hline $\mathbf{T}_{10}$ & Recommended dose of fertilizer & 2.13 & 1.92 & 0.51 & 0.52 & 1.07 & 1.05 \\
\hline & Mean & 2.07 & 1.94 & 0.46 & 0.46 & 1.00 & 0.99 \\
\hline & S.Em + & 0.02 & 0.04 & 0.03 & 0.02 & 0.04 & 0.03 \\
\hline & CD $5 \%$ & NS & NS & NS & NS & NS & NS \\
\hline & CV \% & 1.80 & 1.76 & 13.8 & 13.34 & 7.70 & 7.81 \\
\hline
\end{tabular}

Table.3 Effect of different treatments on nutrient content in straw of fenugreek (02 years)

\begin{tabular}{|c|c|c|c|c|c|c|c|}
\hline \multirow{3}{*}{\multicolumn{2}{|c|}{ Treatments }} & \multicolumn{6}{|c|}{ Nutrient Content in Straw (\%) } \\
\hline & & \multicolumn{2}{|c|}{$\mathbf{N}$} & \multicolumn{2}{|c|}{$\mathbf{P}$} & \multicolumn{2}{|c|}{$\mathbf{K}$} \\
\hline & & 2007-08 & 2008-09 & 2007-08 & 2008-09 & 2007-08 & 2008-09 \\
\hline $\mathbf{T}_{1}$ & $100 \%$ RDN through FYM & 0.73 & 0.78 & 0.14 & 0.14 & 0.38 & 0.38 \\
\hline $\mathbf{T}_{2}$ & $100 \%$ RDN through castor cake & 0.75 & 0.80 & 0.17 & 0.17 & 0.40 & 0.40 \\
\hline $\mathbf{T}_{3}$ & Rhizobium treatment & 0.69 & 0.74 & 0.16 & 0.16 & 0.38 & 0.38 \\
\hline $\mathbf{T}_{4}$ & PSB treatment & 0.70 & 0.75 & 0.16 & 0.16 & 0.42 & 0.42 \\
\hline $\mathbf{T}_{5}$ & Rhizobium + PSB & 0.74 & 0.79 & 0.16 & 0.16 & 0.42 & 0.42 \\
\hline $\mathrm{T}_{6}$ & $50 \%$ RDN through FYM+ Rhizobium & 0.71 & 0.76 & 0.17 & 0.17 & 0.43 & 0.43 \\
\hline$T_{7}$ & $50 \%$ RDN through CC + Rhizobium & 0.73 & 0.78 & 0.14 & 0.14 & 0.39 & 0.39 \\
\hline $\mathrm{T}_{8}$ & $50 \%$ RDN through FYM + Rhizobium + PSB & 0.74 & 0.79 & 0.16 & 0.16 & 0.42 & 0.42 \\
\hline$T_{9}$ & $50 \%$ RDN through CC + Rhizobium + PSB & 0.68 & 0.73 & 0.16 & 0.16 & 0.44 & 0.44 \\
\hline$T_{10}$ & Recommended dose of fertilizer & 0.87 & 0.92 & 0.18 & 0.18 & 0.48 & 0.48 \\
\hline & $\begin{array}{c}\text { Mean } \\
\end{array}$ & 0.73 & 0.78 & 0.16 & 0.16 & 0.42 & 0.42 \\
\hline & S.Em \pm & 0.04 & $\mathbf{0 . 0 3}$ & 0.01 & 0.01 & 0.02 & 0.02 \\
\hline & CD $5 \%$ & NS & NS & NS & NS & NS & NS \\
\hline & $\mathrm{CV} \%$ & 10.10 & 9.42 & 12.80 & 18.21 & 10.20 & 10.15 \\
\hline
\end{tabular}


Table.4 Effect of different treatments on nutrient uptake by seed of fenugreek (02 years)

\begin{tabular}{|c|c|c|c|c|c|c|c|}
\hline \multicolumn{2}{|r|}{ Treatments } & \multicolumn{6}{|c|}{ Nutrient Uptake in Seed $\left(\mathrm{kg} \mathrm{ha}^{-1}\right)$} \\
\hline & & \multicolumn{2}{|c|}{$\mathbf{N}$} & \multicolumn{2}{|c|}{$\mathbf{P}$} & \multicolumn{2}{|c|}{$\mathbf{K}$} \\
\hline & & 2007-08 & 2008-09 & 2007-08 & 2008-09 & 2007-08 & 2008-09 \\
\hline $\mathrm{T}_{1}$ & $100 \%$ RDN through FYM & 16.80 & 16.70 & 3.35 & 3.76 & 8.41 & 8.74 \\
\hline$T_{3}$ & Rhizobium treatment & 16.53 & 13.86 & 3.34 & 3.10 & 7.98 & 6.91 \\
\hline $\mathrm{T}_{4}$ & PSB treatment & 16.07 & 14.14 & 3.59 & 3.50 & 7.97 & 7.24 \\
\hline$T_{5}$ & Rhizobium + PSB & 19.36 & 17.37 & 4.43 & 4.41 & 9.51 & 9.00 \\
\hline$\overline{T_{6}}$ & $50 \%$ RDN through FYM+ Rhizobium & 21.39 & 17.50 & 4.95 & 4.51 & 11.06 & 9.57 \\
\hline $\mathbf{T}_{7}$ & $50 \%$ RDN through CC + Rhizobium & 22.50 & 18.84 & 5.27 & 4.78 & 10.39 & 9.12 \\
\hline$T_{8}$ & $50 \%$ RDN through FYM + Rhizobium + PSB & 23.19 & 19.80 & 5.55 & 5.16 & 10.33 & 9.18 \\
\hline$T_{9}$ & $50 \%$ RDN through CC + Rhizobium+ PSB & 24.88 & 21.32 & 5.29 & 4.99 & 10.91 & 9.77 \\
\hline $\mathrm{T}_{10}$ & Recommended dose of fertilizer & 22.49 & 11.61 & 5.36 & 3.14 & 11.25 & 6.40 \\
\hline & Mean & 20.19 & 16.76 & 4.49 & 4.10 & 4.10 & 8.46 \\
\hline & S.Em + & 1.29 & 0.83 & 0.29 & 0.34 & 0.70 & 0.55 \\
\hline & CD $5 \%$ & 3.75 & 2.41 & 0.84 & 0.98 & 2.04 & 1.66 \\
\hline & CV \% & 12.80 & 9.91 & 12.80 & 16.52 & 14.5 & 13.03 \\
\hline
\end{tabular}

Table.5 Effect of different treatments on nutrient uptake by straw of fenugreek ( 02 years)

\begin{tabular}{|c|c|c|c|c|c|c|c|}
\hline \multicolumn{2}{|r|}{ Treatments } & \multicolumn{6}{|c|}{ Nutrient Uptake in Straw (kg ha ${ }^{-1}$ ) } \\
\hline & & \multicolumn{2}{|c|}{$\mathbf{N}$} & \multicolumn{2}{|c|}{$\mathbf{P}$} & \multicolumn{2}{|c|}{$\mathbf{K}$} \\
\hline & & 2007-08 & 2008-09 & 2007-08 & 2008-09 & 2007-08 & 2008-09 \\
\hline $\mathrm{T}_{1}$ & $100 \%$ RDN through FYM & 11.43 & 20.58 & 2.23 & 3.80 & 5.95 & 10.00 \\
\hline$T_{2}$ & $100 \%$ RDN through castor cake & 12.86 & 20.76 & 2.81 & 4.31 & 6.88 & 10.50 \\
\hline $\mathbf{T}_{3}$ & Rhizobium treatment & 8.24 & 17.64 & 1.92 & 3.89 & 4.58 & 8.99 \\
\hline $\mathbf{T}_{4}$ & PSB treatment & 9.63 & 17.67 & 2.23 & 3.86 & 5.77 & 9.78 \\
\hline $\mathbf{T}_{5}$ & Rhizobium + PSB & 10.44 & 20.66 & 2.23 & 4.13 & 5.92 & 11.05 \\
\hline $\mathrm{T}_{6}$ & $50 \%$ RDN through FYM+ Rhizobium & 12.77 & 20.92 & 3.05 & 4.60 & 7.71 & 11.78 \\
\hline $\mathbf{T}_{7}$ & $50 \%$ RDN through CC + Rhizobium & 15.52 & 21.47 & 2.97 & 3.85 & 8.27 & 10.67 \\
\hline $\mathbf{T}_{8}$ & $50 \%$ RDN through FYM + Rhizobium+ PSB & 15.44 & 21.22 & 3.27 & 4.22 & 8.73 & 11.20 \\
\hline $\mathrm{T}_{9}$ & $50 \%$ RDN through CC + Rhizobium+ PSB & 15.03 & 20.86 & 3.49 & 4.51 & 9.81 & 12.82 \\
\hline$T_{10}$ & Recommended dose of fertilizer & 18.32 & 15.89 & 3.71 & 3.06 & 10.17 & 8.39 \\
\hline & $\begin{array}{c}\text { Mean } \\
\end{array}$ & 12.97 & 19.77 & 2.79 & 4.02 & 7.38 & 10.52 \\
\hline & S.Em + & 0.79 & 1.66 & 0.24 & 0.37 & 0.53 & 0.96 \\
\hline & CD $5 \%$ & 2.29 & NS & 0.68 & NS & 1.55 & NS \\
\hline & $\mathrm{CV} \%$ & 12.30 & 16.80 & 16.90 & 18.21 & 14.50 & 18.21 \\
\hline
\end{tabular}


Table.6 Effect of different treatments on organic carbon, phosphorus and potassium content in Soil after harvest of fenugreek (02 years)

\begin{tabular}{|c|c|c|c|c|c|c|c|}
\hline \multicolumn{2}{|r|}{ Treatments } & \multicolumn{2}{|c|}{$\mathrm{OC}(\%)$} & \multicolumn{2}{|c|}{ Available $\mathbf{P}\left(\mathrm{kg} \mathrm{ha}^{-1}\right)$} & \multicolumn{2}{|c|}{ Available $\mathrm{K}\left(\mathrm{kg} \mathrm{ha}^{-1}\right)$} \\
\hline & & 2007-08 & 2008-09 & 2007-08 & 2008-09 & 2007-08 & 2008-09 \\
\hline $\mathbf{T}_{1}$ & $100 \%$ RDN through FYM & 0.28 & 0.31 & 36.38 & 36.87 & 158.71 & 162.46 \\
\hline $\mathbf{T}_{2}$ & $100 \%$ RDN through castor cake & 0.28 & 0.31 & 35.09 & 35.84 & 154.72 & 159.22 \\
\hline $\mathbf{T}_{\mathbf{3}}$ & Rhizobium treatment & 0.21 & 0.25 & 33.67 & 34.87 & 142.77 & 148.39 \\
\hline $\mathbf{T}_{4}$ & PSB treatment & 0.22 & 0.26 & 45.51 & 46.00 & 153.32 & 157.07 \\
\hline $\mathbf{T}_{5}$ & Rhizobium + PSB & 0.21 & 0.26 & 40.64 & 41.12 & 156.12 & 159.87 \\
\hline $\mathrm{T}_{6}$ & $50 \%$ RDN through FYM+ Rhizobium & 0.24 & 0.27 & 37.26 & 37.90 & 158.92 & 162.67 \\
\hline $\mathbf{T}_{7}$ & $50 \%$ RDN through CC + Rhizobium & 0.24 & 0.27 & 36.38 & 36.87 & 158.71 & 162.46 \\
\hline $\mathbf{T}_{8}$ & $50 \%$ RDN through FYM + Rhizobium+ PSB & 0.25 & 0.28 & 43.39 & 44.03 & 153.43 & 157.18 \\
\hline $\mathbf{T}_{9}$ & $50 \%$ RDN through CC + Rhizobium + PSB & 0.26 & 0.29 & 45.26 & 45.90 & 165.60 & 170.85 \\
\hline $\mathbf{T}_{10}$ & Recommended dose of fertilizer & 0.26 & 0.29 & 43.60 & 44.08 & 164.31 & 172.18 \\
\hline & Mean & 0.24 & 0.28 & 39.72 & 40.35 & 156.66 & 161.24 \\
\hline & S.Em \pm & 0.01 & 0.01 & 2.24 & 2.19 & 5.66 & 5.23 \\
\hline & CD $5 \%$ & 0.04 & 0.04 & 6.50 & 6.34 & NS & NS \\
\hline & $\mathrm{CV} \%$ & 10.20 & 9.33 & 11.30 & 10.40 & 7.20 & 6.49 \\
\hline
\end{tabular}


But in case of second year significantly maximum potassium uptake by grain $(9.77 \mathrm{~kg}$ $\mathrm{ha}^{-1}$ ) was recorded due to application of $50 \%$ $\mathrm{RDN}$ through $\mathrm{CC}+$ Rhizobium $+\mathrm{PSB}$ as compared to other treatments.

Significantly, maximum nitrogen uptake by straw (18.32 $\mathrm{kg} \mathrm{ha}^{-1}$ ) was recorded due to application of recommended dose of fertilizer during first year. But in case of second year significantly, maximum nitrogen uptake by straw (21.47 $\mathrm{kg} \mathrm{ha}^{-1}$ ) was recorded due to application $50 \%$ RDN through $\mathrm{CC}+$ Rhizobium as compared to other treatments. Significantly, the highest phosphorus uptake by seed (3.49 and $4.51 \mathrm{~kg} \mathrm{ha}^{-1}$ ) was recorded due to application of $50 \% \mathrm{RDN}$ through CC + Rhizobium + PSB as compared to other treatments during both individual years. Significantly, maximum potassium uptake by grain $\left(10.17 \mathrm{~kg} \mathrm{ha}^{-1}\right)$ was recorded due to application of recommended dose of fertilizer during first year. But in case of second year significantly, maximum potassium uptake by grain $\left(12.82 \mathrm{~kg} \mathrm{ha}^{-1}\right)$ was recorded due to application $50 \%$ RDN through $\mathrm{CC}+$ Rhizobium+ PSB as compared to other treatments (Table 3-5).

\section{Soil status after harvest}

The organic carbon and available phosphorus were also found significant due to different treatments; whereas the maximum amount of organic carbon $(0.28 \%)$ was registered under $100 \%$ RDN through FYM/castor cake, which was found statistically at par with remaining treatments except sole use of biofertilizers. The maximum available phosphorus (45.51 $\mathrm{kg} \mathrm{ha}^{-1}$ ) was recorded with the use of PSB, which was statistically at par with $\mathrm{F}_{5}, \mathrm{~F}_{8}, \mathrm{~F}_{9}$ and $F_{10}$. The available potassium was found non-significant due to different treatments. The use of microbial cultures under different organic modules increased $\mathrm{N}_{2}$ fixation, solubilisation of $\mathrm{P}$ and $\mathrm{K}$. Further the root system of the legumes has capacity to solubilise soil phosphorus through extraction of amino acid which encourages the growth and multiplication of soil microbes which finally leads to mineralization of unavailable $\mathrm{P}$ to available $\mathrm{P}$ in soil (Table 6). The results corroborate the findings of Malik et al., 2013 and Singh et al., 2013.

\section{References}

Balachandran, D. and Nagarajan, P. 2002. Dual inoculation of Rhizobium and phosphobacteria with phosphorus on black gram cv. Vamban1. Madras Agril. J. 89:691-693.

Darzi, M.T., Ghalavand, A. and Rejali, F. 2008. Effect of mycorrhiza, vermicompost and phosphate biofertilizers application on flowering, biological yield and root colonization in fennel (Foeniculum vulgare L). Iranian J. Crop Sci. 10: 88-109.

Darzi, M.T., Haj, S., Hadi, M.R. and Rejali, F. 2011. Effect of vermicompost and phosphate biofertilizer application on yield and yield components in Anise (Pimpinella anisum L.) Iranian J. Med. Aroma. Plants 4:452-465.

Gyaneshwar, P., Kumar, N.G., Parekh, L.J. and Poole, P.S. 2002. Role of soil microorganisms in improving $P$ nutrition of plants. Plant. Soil 245:8393.

Lal, G. and Singh, R. 2016. Comprehensive evaluation of coriander (Coriandrum sativum L.) varieties under different organic modules. Indian Journal of Agricultural Sciences 86: 31-36.

Lal, G.; Singh, B.; Mehta, R.S.; Singh, R. and Maheria, S.P. 2015. Performance of fenugreek (Trigonella foenum graecum L.) as influenced by sulphur and zinc. Int. J. Seed Spices 5: 29-33.

Lampkin, N.H. 1999. Organic farming: sustainable agriculture in practice. In: 
the economics of organic farming- an international perspective. Eds. Lumpkin, N.H. and Padel, S. 3-9. CAB International, U.K.

Malik, J. K.; Singh, R.; Thenua, O. V. S. and Kumar, A. 2013. Performance of sole and inter cropped pigeonpea (Cajanus cajan) + mungbean (Phaseolus radiatus) as influenced by phosphorus and biofertilizers. Legume Research 36: 323-330.

Mehta, R.S., Godara A.S., and Meena B.S. 2011. Effect of nitrogen, phosphorus and bio-fertilizer levels on yield attributes, yield and economics of fenugreek (Trigonella foenum graecum L.). Prog. Hort. 43: 271-275.

Mehta, R.S., Patel, B.S., Meena S.S and Meena R.S. 2010. Influence of nitrogen, phosphorus and biofertilizers on growth characters and yield of fenugreek (Trigonella foenum-graecum L.) J. Spices Aroma. Crops 19: 23-28.

Nagarajan, P. and Balachandran, D. 2001. Influence of Rhizobium and organic amendment on nodulation and grain yield of black gram, green gram in acid soil. Madras Agric. J. 88: 703-705.

Palaniappan, S.P. and Annadurai, K. 1999. Organic Farming: Theory and Practices. Scientific Publishers, Jodhpur.

Saxena, H.S., Manral, T.K. and Chandel, A.S. 2001. Effect of organic and inorganic sources of nutrients on soybean (Glycine max). Indian J. Agro. 46: 135140.

Sibbal, Anshu and Khurana, A.S. 2002. Host cultivar Rhizobium interaction in chickpea (Cicer arietinum L.). Legume Research 25:21-26.

Singh, R., Malik, J. K., Thenua, O.V.S. and Jat, H. S. 2013. Effect of phosphorus and bio-fertilizer on productivity, nutrient uptake and economics of pigeonpea (Cajanus cajan) + mungbean (Phaseolus radiatus) intercropping system. Legume Research 36: 41-48.

Tiwari, R.K., Mistry, N.C., Singh, B. and Gandhi, C.P. 2013. Crop wise area, production and productivity of major spices in India. Indian Horticulture Database, pp. 06.

\section{How to cite this article:}

Malav, J.K., J.K. Patel, R.P. Pavaya, B.B. Patel and Patel, V.R. 2018. Effect of Different Organic Sources on Fenugreek (Trigonella foenum-graecum L.) under Organic Farming Module. Int.J.Curr.Microbiol.App.Sci. 7(02): 17-25. doi: https://doi.org/10.20546/ijcmas.2018.702.004 